\title{
Utilisation of cement-asbestos wastes by thermal treatment and the potential possibility use of obtained product for the clinker bricks manufacture
}

\author{
Robert Kusiorowski $^{1,2} \cdot$ Teresa Zaremba $^{1} \cdot$ Jerzy Piotrowski $^{1}$ • \\ Jacek Podwórny ${ }^{2}$
}

Received: 7 April 2015/Accepted: 2 July 2015/Published online: 9 July 2015

(C) The Author(s) 2015. This article is published with open access at Springerlink.com

\begin{abstract}
The aim of this study was to investigate the thermal behaviour of cement-asbestos wastes and to determine whether it is possible to use them in the production of building ceramics, e.g. clinker bricks. In the first part of the research, the process of cement-asbestos thermal decomposition was studied. This asbestos material contained the chrysotile and crocidolite variety of asbestos. The results of this study allowed to determine the lowest temperature of thermal treatment that provides asbestos detoxification. The second part of the paper presents the results of a preliminary study on using previously calcined cement-asbestos wastes as an additive to ceramic masses typical for clinker bricks. Green compacts containing various amounts of cement-asbestos wastes were sintered and then ceramic properties were determined. The results of the study indicate that calcined asbestos-containing materials can be used as one of the secondary raw materials in the production of clinker ceramics.
\end{abstract}

\section{Introduction}

Asbestos is the commercial name for several types of naturally occurring fibrous silicate minerals. These minerals are divided into two main groups: serpentine and

Robert Kusiorowski

r.kusiorowski@icimb.pl; robert.kusiorowski@interia.pl

1 Department of Inorganic, Analytical Chemistry and Electrochemistry, Faculty of Chemistry, Silesian University of Technology, B. Krzywoustego Str. 6, 44-100 Gliwice, Poland

2 Refractory Materials Division in Gliwice, Institute of Ceramics and Building Materials, Toszecka Str. 99, 44-100 Gliwice, Poland amphibole asbestos. Serpentines are hydrous magnesium silicates and they occur as one asbestiform, fibrous mineral: chrysotile (white asbestos) with an ideal chemical formula, $\mathrm{Mg}_{3}(\mathrm{OH})_{4}\left(\mathrm{Si}_{2} \mathrm{O}_{5}\right)$. This mineral with sheet structure was the most often commercially used form of asbestos and covered more than $90 \%$ of world production of asbestos. Amphiboles are double-chain silicates and contain five asbestiform minerals with an ideal chemical formula: actinolite $\mathrm{Ca}_{2}(\mathrm{Mg}, \mathrm{Fe})_{5}\left[(\mathrm{OH}) \mathrm{Si}_{4} \mathrm{O}_{11}\right]_{2}$, amosite $(\mathrm{Fe}, \mathrm{Mg})_{7}$ $\left[(\mathrm{OH}) \mathrm{Si}_{4} \mathrm{O}_{11}\right]_{2}$, anthophyllite $(\mathrm{Mg}, \mathrm{Fe})_{7}\left[(\mathrm{OH}) \mathrm{Si}_{4} \mathrm{O}_{11}\right]_{2}$, crocidolite $\mathrm{Na}_{2} \mathrm{Fe}_{3} \mathrm{Fe}_{2}\left[(\mathrm{OH}) \mathrm{Si}_{4} \mathrm{O}_{11}\right]_{2}$, and tremolite $\mathrm{Ca}_{2} \mathrm{Mg}_{5}$ $\left[(\mathrm{OH}) \mathrm{Si}_{4} \mathrm{O}_{11}\right]_{2}$. Among these amphibole minerals, only crocidolite (blue asbestos) and amosite (brown asbestos) were used on a large industrial scale [1, 2].

Due to the preferred usable features such as nonflammability, mechanical and tensile strength, electrical, heat or sound insulating properties and chemical resistance, asbestos minerals were widely used in the past for various industrial applications. The main direction of asbestos use was the widely understood building industry. The most popular products based on asbestos were cement-asbestos assortments. About $85 \%$ of asbestos imported to Poland was used for their production [3]. The huge popularity of cement-asbestos in the building industry of the twentieth century stemmed from its inexpensive production process combined with ease of forming various shapes. The most extensive use has been in flat sheets, tiles, corrugated sheets for roofing, rainwater and pressure pipes. Cementasbestos products usually contained $10-16 \mathrm{wt} \%$ of asbestos, whose main function was fibrous reinforcement in the cement [4].

Generally, the asbestos era ended in developed countries in the late twentieth century when the carcinogenic properties of asbestos were discovered and confirmed by many studies. On the other hand, it should also be noted that there 
are still countries where the manufacture and use of asbestos-containing materials is not prohibited [5]. Currently, asbestos minerals are considered as hazardous material for people that cause lung diseases such as asbestosis or lung cancer. The most dangerous are the respirable fibres, which have a length greater than $5 \mu \mathrm{m}$, a diameter less than $3 \mu \mathrm{m}$ and a length-to-diameter ratio above $3: 1[6,7]$. In many countries there is only one way of dealing with these dangerous wastes, which are stored in controlled landfill sites [8]. This procedure does not completely solve the asbestos problem because the fibrous structure of asbestos is not destroyed-it is only isolated from the human environment.

In the literature there are several reports about possible utilisation methods of asbestos- containing materials which generally describe the destruction of the asbestos fibrous structure by dissolution in an acidic environment [9-12], melting and subsequent solidification [13-15], amorphisation by mechanochemical techniques [16, 17], or by biological method [18]. Asbestos-containing wastes can also be subject to classic heat treatment (calcination, annealing) at a sufficiently high temperature, providing thermal decomposition of asbestos minerals. The last method is most commonly presented in the specialist literature [1922] because of its simplicity in implementation and potentially wide range of proposed applications of the obtained product after thermal treatment, e.g. as secondary ceramic raw material [23-26].

The thermal utilisation method of asbestos minerals is quite well known, especially with respect to chrysotile asbestos, and has been described in the specialist literature [27-30]. Generally, this method is associated with the dehydroxylation process of asbestos minerals and in designating the optimal temperature of thermal treatment. In the case of cement-asbestos materials, these investigations can be more complicated due to the multiphase reacting system. The reaction paths should be completely modified due to the presence of other cementitious phases and operating conditions, e.g. varying degrees of exposure to weather conditions in which the cement-asbestos assortment was used [31-33].

Important results were provided in a study by Italian researchers [34] who studied more than 25 cement-asbestos samples removed from different locations in Italy. Chemical analysis of the tested samples showed significant differences in the chemical composition (expressed as oxides); for example, the content of $\mathrm{SiO}_{2}$ ranged from 21.8 to $45.2 \mathrm{wt} \%$, while the $\mathrm{CaO}$ content changed from 26.7 to $38.4 \mathrm{wt} \%$. Other components were also changed to a lesser or greater extent. Phase composition as determined by the $\mathrm{X}$-ray analysis method was also varied. Generally, among all of the tested samples the authors identified 25 different crystalline phases. In aged cement-asbestos samples, calcite was the most abundant detected crystalline phase. On the other hand, the weight fraction of the amorphous fraction not determined by XRD analysis was quite variable and ranged from 9.5 to $66.6 \mathrm{wt} \%$. Chrysotile asbestos was identified in all samples, while amphibole asbestos (without distinction as to the type of amphibole asbestos) was detected in 17 out of 29 samples. The authors also identified products of cement hydration and unreacted clinker phases. According to the authors, batches of cement-asbestos materials from different plants, in particular slates and undergoing the same thermal treatment, may yield different end products. This was confirmed by studies presented by Viani et al. [35], in which the high-temperature inertisation product of a representative batch of previously mentioned cement-asbestos samples was characterised. The chemistry of the investigated samples is dominated by $\mathrm{Si}, \mathrm{Ca}$ and $\mathrm{Mg}$, although significant differences between the samples exist. All of the raw cementasbestos samples were heated at $1200{ }^{\circ} \mathrm{C}$ for $15 \mathrm{~min}$ and then were characterised with a combination of analytical techniques. A series of solid state reactions leading to global structural changes of the matrix with a complete transformation of asbestos minerals was observed. After thermal treatment, phase composition was determined by XRD analysis in which the authors found about 25 crystalline phases in the cement-asbestos materials in various proportions depending on the origin of the cement-asbestos waste. The authors identified three classes of product obtained by high-temperature cement-asbestos treatment. They indicated that the obtained material may belong to a larnite-rich, bredigite-rich or akermanite-rich product and hence can find various further applications.

The aim of the research presented in this study was (i) to determine thermal stability as well as structural and phase changes of cement-asbestos corrugated sheet during the calcination process to a high temperature and to classify it into one of the above-mentioned classes (ii) to select the minimal temperature of cement-asbestos thermal treatment at which the dangerous properties of asbestos disappeared, and (iii) to demonstrate the possibility of using previously thermally treated cement-asbestos material as a secondary raw material in the manufacture of clinker ceramics used as a building material.

\section{Experimental}

The subject of examination was corrugated cement-asbestos slate. The slate came from Upper Silesia (Poland), from around the city of Mikołów. The slate had been exposed to outside weather conditions for about 30 years. The asbestos material was the façade and roof panels of a shed. Different types of asbestos were observed in the 
fracture of a sample, e.g. there were yellowish-green and dark-blue bundles of fibres, potentially chrysotile and crocidolite asbestos, respectively. This cement-asbestos material was subjected to classical wet chemical analysis and the main chemical components were determined by standard laboratory procedure applied for the chemical analysis of aluminosilicate materials. The cement-asbestos sample was fused with a mixture of sodium carbonate and sodium tetraborate, evaporated to dryness with concentrated hydrochloric acid for isolation of silicic acid anhydride and then filtered and calcined for the resulting precipitate. The resulting filtrate was used for further assays for which $\mathrm{Fe}_{2} \mathrm{O}_{3}, \mathrm{Al}_{2} \mathrm{O}_{3}, \mathrm{CaO}$ and $\mathrm{MgO}$ contents were determined by titration with EDTA (ethylenediaminetetraacetic acid sodium salt complexing agent) against appropriate indicators. The $\mathrm{SiO}_{2}$ content was determined using the gravimetric method by stripping silicic acid anhydride using hydrofluoric acid. The $\mathrm{SO}_{3}$ content was also determined gravimetrically by dissolving the sample in hydrochloric acid and following precipitation of sulphate ions by barium ions. Loss on ignition (LOI) was determined by annealing in a laboratory oven at $1000{ }^{\circ} \mathrm{C}$ to a constant weight.

This cement-asbestos waste was subjected to ex situ $\mathrm{X}$-ray analysis (XRD), Fourier transform infrared spectroscopy (FT-IR) as well as differential thermal analysis (DTA) and thermogravimetry (TG). Moreover, its microstructure was observed by scanning electron microscopy (SEM). In order to accurately determine the temperature range of the disappearance of asbestos mineral by thermal treatment and change in phase composition, hightemperature X-ray measurement (in situ method; HT-XRD) was applied. The minimal temperature of cement-asbestos thermal treatment was selected based on the obtained results. Then, to check for potential usability of cementasbestos waste as a secondary raw material for the production of clinker ceramics, the waste was subjected to initial calcination in a laboratory furnace at a selected temperature for $2 \mathrm{~h}$. The obtained product was also characterised by XRD, FT-IR, DTA/TG and SEM analysis.

Thermal analysis (DTA and TG) was performed using a Paulik-Paulik-Erdey type derivatograph (MOM, Hungary) within the range of temperature of $20-1000{ }^{\circ} \mathrm{C}$. The conditions were as follows: mass of sample $500 \mathrm{mg}$, air atmosphere, heating rate $10 \mathrm{~K} \mathrm{~min}^{-1}$, alumina crucible and $\mathrm{Al}_{2} \mathrm{O}_{3}$ as the reference material. XRD analysis of the examined samples was carried out using a PANalytical X'pert Pro diffractometer $\left(\mathrm{CuK}_{\alpha}\right.$ radiation, Ni filter, $40 \mathrm{kV}$, $30 \mathrm{~mA}, \mathrm{X}^{\prime}$ Celerator detector). The in situ high-temperature diffraction experiment was conducted using the same diffractometer equipped with an Anton Paar HTK2000 heating chamber. X-ray diffraction patterns were collected in continuous mode in a range of $6^{\circ}-55^{\circ} 2 \theta$. Data were collected in the temperature range of $25-1200{ }^{\circ} \mathrm{C}$, at steps of $100{ }^{\circ} \mathrm{C}$ with additional measurement at $650{ }^{\circ} \mathrm{C}$. IRspectra were measured on a Nicolett 6700 FT-IR spectrophotometer (ATR method). The microstructure of the samples was examined by a scanning electron microscope (Hitachi TM-3000). Observations were made after coating the sample surfaces with a thin layer of gold in order to obtain conductivity.

A commercial raw mix of ceramic clinker was used (CRH Klinkier; Patoka, Poland) in the second stage of the study during which recycling tests were carried out. The chemical composition of used commercial raw mix of ceramic clinker is as follows: $\mathrm{SiO}_{2} 62.4 \mathrm{wt} \%, \mathrm{Al}_{2} \mathrm{O}_{3}$ $17.0 \mathrm{wt} \%, \mathrm{Fe}_{2} \mathrm{O}_{3} 9.5 \mathrm{wt} \%, \mathrm{TiO}_{2} 0.8 \mathrm{wt} \%, \mathrm{CaO} 0.4 \mathrm{wt} \%$, $\mathrm{MgO} 1.3 \mathrm{wt} \%, \mathrm{~K}_{2} \mathrm{O} \quad 2.0 \mathrm{wt} \%, \quad \mathrm{MnO} 0.2 \mathrm{wt} \%$, LOI $6.3 \mathrm{wt} \%$. Mineral composition of used commercial raw mix contains clay and non-clay minerals. Among clay minerals a principal role is played by kaolinite (ICDD-PDF 00-058-2028). Illite (ICDD-PDF 00-026-0911) is present as an admixture. Non-clay minerals are represented by quartz (ICDD-PDF 01-070-3755), muscovite (ICDD-PDF 01-070-3754) and siderite (ICDD-PDF 00-029-0696).

Different amounts of previously calcined cement-asbestos $(0-10 \mathrm{wt} \%)$ were added as a leaning agent, i.e. a component that reduces shrinkage, to this mass. The raw materials had the following grain size: $<1 \mathrm{~mm}$ for clay and $<0.5 \mathrm{~mm}$ for calcined cement-asbestos. The mixtures were homogenised in a ball-mill for $15 \mathrm{~min}$, then mixing water was added ( $15 \mathrm{wt} \%$ to obtain semi-dry masses) and further homogenised for $24 \mathrm{~h}$ in a closed foil bag. The green samples, formed as cylinders $(30 \mathrm{~mm}$ in diameter and about $30 \mathrm{~mm}$ in height, uniaxial compression at $15 \mathrm{MPa}$ ), were dried in room temperature and in a laboratory dryer at $105^{\circ} \mathrm{C}$. Then they were sintered at 1100,1150 and $1200{ }^{\circ} \mathrm{C}$ for $1 \mathrm{~h}$ at maximum temperature. Finally, these samples were naturally cooled in a furnace until they reached room temperature. After thermal treatment, total linear shrinkage, water absorption, open porosity, apparent density and compressive strength were measured on representative samples following standard laboratory procedures. Freeze resistance was also determined.

\section{Results and discussion}

\section{Characterisation of the cement-asbestos material and its thermal decomposition}

The chemical composition of the investigated cement-asbestos sample is reported in Table 1. These values are close to the results obtained in a chemical analysis by Witek et al. [36], where the content of the main chemical components was as follows: $\mathrm{CaO} 41.8 \mathrm{wt} \%, \mathrm{SiO}_{2} 19.3 \mathrm{wt} \%$ 
Table 1 Main chemical components of cement-asbestos waste

\begin{tabular}{lc}
\hline Item & Content (wt\%) \\
\hline $\mathrm{SiO}_{2}$ & 18.5 \\
$\mathrm{CaO}$ & 41.9 \\
$\mathrm{MgO}$ & 3.7 \\
$\mathrm{Al}_{2} \mathrm{O}_{3}$ & 2.7 \\
$\mathrm{Fe}_{2} \mathrm{O}_{3}$ & 3.4 \\
$\mathrm{SO}_{3}$ & 1.9 \\
$\mathrm{LOI}$ & 25.5 \\
\hline
\end{tabular}

LOI loss on ignition and LOI $25.1 \mathrm{wt} \%$. Generally, the composition is also similar to that in samples tested by Viani et al. [34]. Values of the $\mathrm{SO}_{3}$ and $\mathrm{MgO}$ content and loss on ignition are in the range reported by the Italian study [34]. In the considered cement-asbestos sample, the $\mathrm{SiO}_{2}$ content is slightly smaller than the minimal participation in the Italian samples (18.5 vs. $21.8 \mathrm{wt} \%$ ), while the $\mathrm{CaO}$ content is the biggest (41.9 vs. the $26.7-38.4 \mathrm{wt} \%$ range reported in [34]). This difference may be due to the different manufacturing processes of cement-asbestos and the ageing process, with varying intensity depending on the region and the time during which the cement-asbestos materials were used. According to [34], quartz was often used as a filler in Italian cement-asbestos products. Cement-asbestos manufacturers in Poland rather did not use additional mineral fillers. In the tested sample an increased content of $\mathrm{Fe}_{2} \mathrm{O}_{3}$ (3.4 vs. 2.9 wt\% [36]) was also observed. This can be explained by the presence of crocidolite (blue asbestos) which increased the iron content in the sample.

Figure 1 shows the XRD patterns of the raw cementasbestos sample and that calcined at a selected temperature $\left(700{ }^{\circ} \mathrm{C}\right)$. This raw cement-asbestos sample contained both chrysotile (ICDD-PDF 00-027-1276) and crocidolite (ICDD-PDF 00-060-0343) asbestos. This is confirmed by the two strongest diffraction interferences originating from these asbestos minerals at $11^{\circ}-12^{\circ} 2 \theta$. It can be observed that the main crystalline phases of raw cement-asbestos waste were calcium carbonate $\mathrm{CaCO}_{3}$ (as calcite and vaterite (ICDD-PDF 04-012-8072, ICDD-PDF 00-0600483, respectively)) and portlandite $\mathrm{Ca}(\mathrm{OH})_{2}$ (ICDD-PDF 04-006-9147). Ettringite (ICDD-PDF 00-041-1451) and gypsum (ICDD-PDF 04-009-3817) as well as $\beta$-dicalcium silicate (ICDD-PDF 01-083-0461), tricalcium silicate (ICDD-PDF 04-014-9801), katoite (ICDD-PDF 00-0380368) and traces of quartz (ICDD-PDF 00-033-1161) were also identified. Portlandite is one of the main products of the cement hydration process where the formation of calcium silicate hydrates (CSH phase) also occurs. The CSH phases generally possess a low degree of crystallinity and are X-ray amorphous, so they are rather not visible on the XRD patterns. In this cement-asbestos sample study, only the hydrogarnet of the katoite-hibschite series $\mathrm{Ca}_{3} \mathrm{Al}_{2}$ $\left(\mathrm{SiO}_{4}\right)_{3-x}(\mathrm{OH})_{4 x}$ is the best represented and detected hydrated crystalline phase. Calcium carbonates are the main products of weathering as observed in the cementasbestos sample. Their presence is due to the carbonation process of the cement matrix with atmospheric $\mathrm{CO}_{2}$. Gypsum and ettringite are observed because gypsum $\mathrm{CaSO}_{4} \cdot 2 \mathrm{H}_{2} \mathrm{O}$ was added as the setting-time regulator for cement and because they may be created as a result of interaction with the environment (acid rain). In the presence of gypsum the calcium aluminate of cement clinker reacts with water, producing ettringite $\mathrm{Ca}_{6} \mathrm{Al}_{2}\left(\mathrm{SO}_{4}\right)_{3}$ $(\mathrm{OH})_{12} \cdot 26 \mathrm{H}_{2} \mathrm{O}$. $\beta$-dicalcium silicate and tricalcium silicate were observed as unreacted clinker phases of cement.

Figure 2 shows the results of the in situ diffraction experiments (HT-XRD). From a technological point of view and with regard to the potential for thermal utilisation of cement-asbestos waste, the temperature range in which the diffraction interferences of asbestos minerals disappear is the most important. Due to the presence of two asbestos minerals in the considered sample (chrysotile and crocidolite), the absence of X-ray peaks of both types of asbestos is required. The obtained results show that with an increase in temperature the strongest asbestos diffraction interferences disappear at about $700{ }^{\circ} \mathrm{C}$, which is marked as a loop in Fig. 2. Figure 3 was created based on HT-XRD measurement and reports the field of stability of all original and newly formed crystalline phases in the considered cement-asbestos sample with an increase in temperature to a maximum firing temperature of $1200{ }^{\circ} \mathrm{C}$. The first phases to decompose are ettringite and katoite, with loss of water up to a temperature of $100{ }^{\circ} \mathrm{C}$. According to [37], ettringite begins losing water at $70{ }^{\circ} \mathrm{C}$ and the short-range order in the crystal structure is disrupted. The thermal treatment product of ettringite becomes XRD-amorphous. In a temperature range of $100-200{ }^{\circ} \mathrm{C}$, the presence of gypsum disappeared. Gypsum decomposed to anhydrite according to the reaction: $\mathrm{CaSO}_{4} \cdot 2 \mathrm{H}_{2} \mathrm{O} \rightarrow \mathrm{CaSO}_{4} \cdot 1 / 2 \mathrm{H}_{2} \mathrm{O}+3 / 2 \mathrm{H}_{2} \mathrm{O} \rightarrow$ $\mathrm{CaSO}_{4}+1 / 2 \mathrm{H}_{2} \mathrm{O}$. The thermal decomposition products of katoite and gypsum are not visible on the XRD patterns, most probably due to poor crystallinity and low content in the obtained material after thermal treatment. Between 400 and $500{ }^{\circ} \mathrm{C}$, subsequent phases of the cementitious matrix undergo a thermal transformation. In this temperature range portlandite decomposes according to the reaction: $\mathrm{Ca}(\mathrm{OH})_{2} \rightarrow \mathrm{CaO}+\mathrm{H}_{2} \mathrm{O}$; vaterite is also converted to calcite. According to the literature [38], at a temperature of $\sim 460{ }^{\circ} \mathrm{C}$ vaterite was subjected to the vaterite-calcite phase transition. Most interesting are the conclusions regarding asbestos stability. Both of the tested asbestos minerals, i.e. chrysotile and crocidolite, from the used cement-asbestos slate are stable up to a temperature of $600{ }^{\circ} \mathrm{C}$. After measurement at a temperature of about 


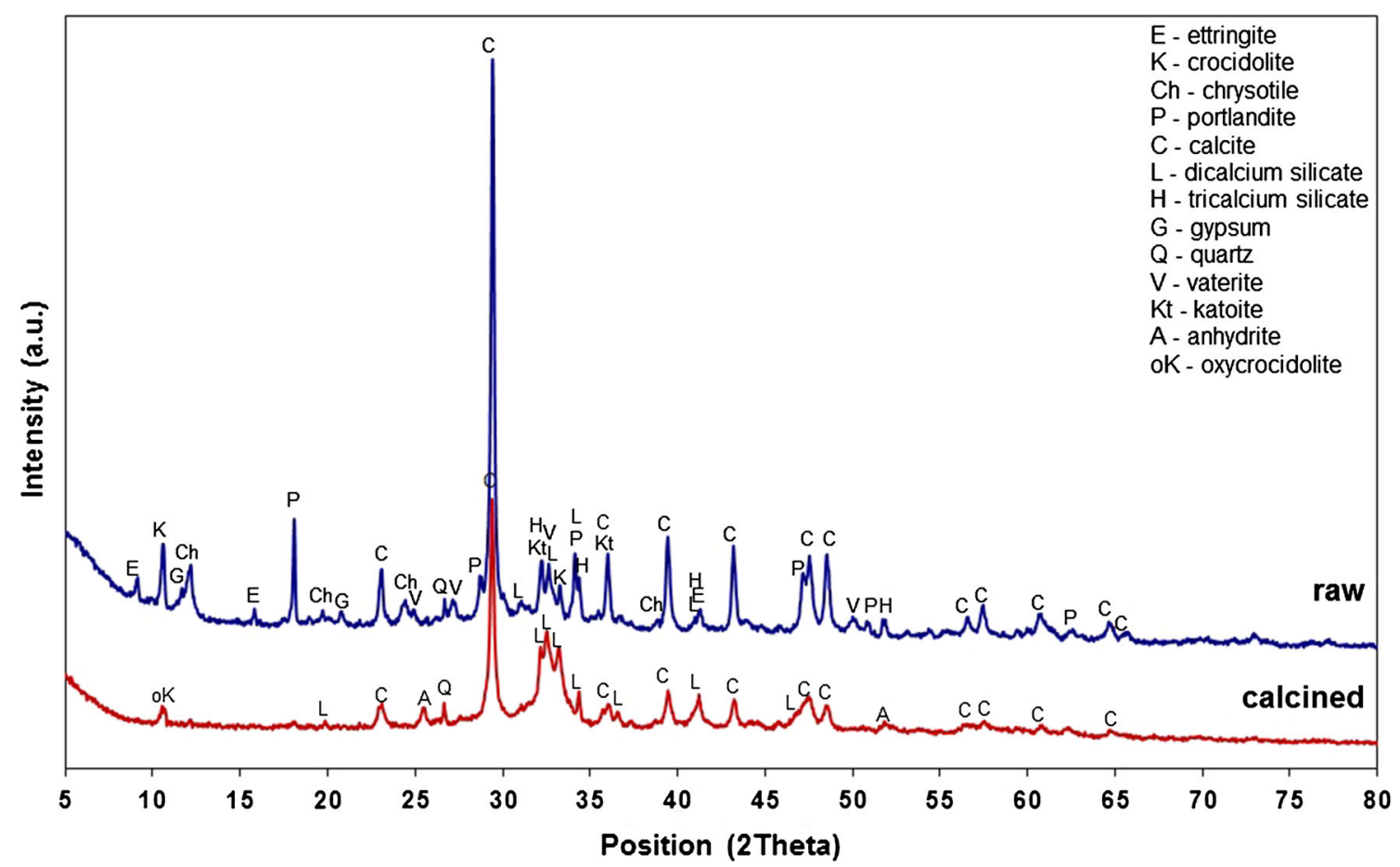

Fig. 1 XRD patterns of raw cement-asbestos sample and after thermal treatment at $700{ }^{\circ} \mathrm{C}$ for $2 \mathrm{~h}$

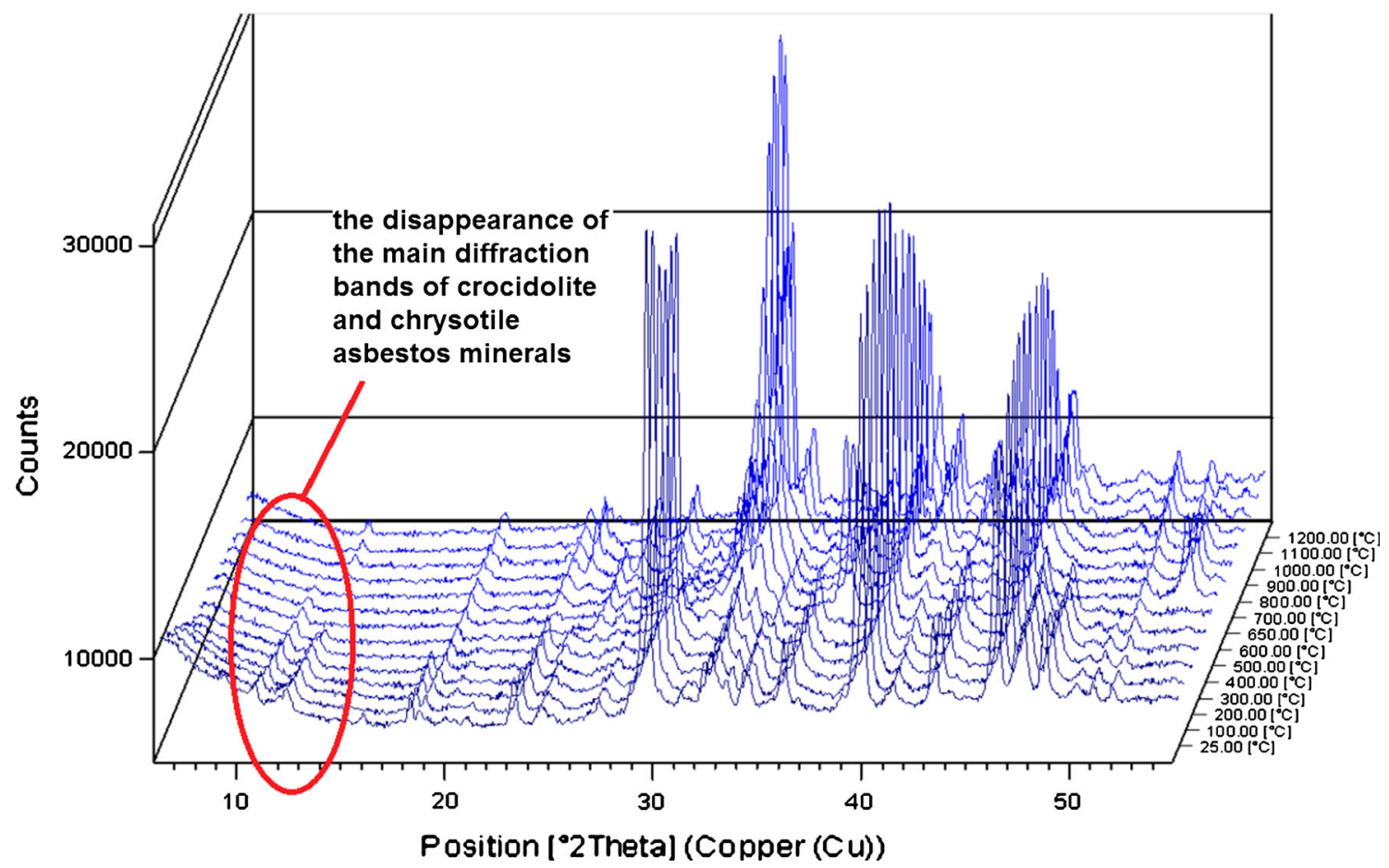

Fig. 2 HT-XRD patterns of cement-asbestos sample

$800{ }^{\circ} \mathrm{C}$ the chrysotile diffraction interferences were already absent (specific interferences disappear at $650{ }^{\circ} \mathrm{C}$ ), while for crocidolite asbestos only slightly marked traces were observed. It comes from so-called oxycrocidolite. This is pseudomorph of crocidolite asbestos after its thermal decomposition and dehydroxylation process. However, the temperature $700{ }^{\circ} \mathrm{C}$ is sufficient for the thermal decomposition of crocidolite, which was confirmed by previous 
Fig. 3 The temperature stability ranges of the crystalline phases in the cement-asbestos sample; narrow strip-traces of phase

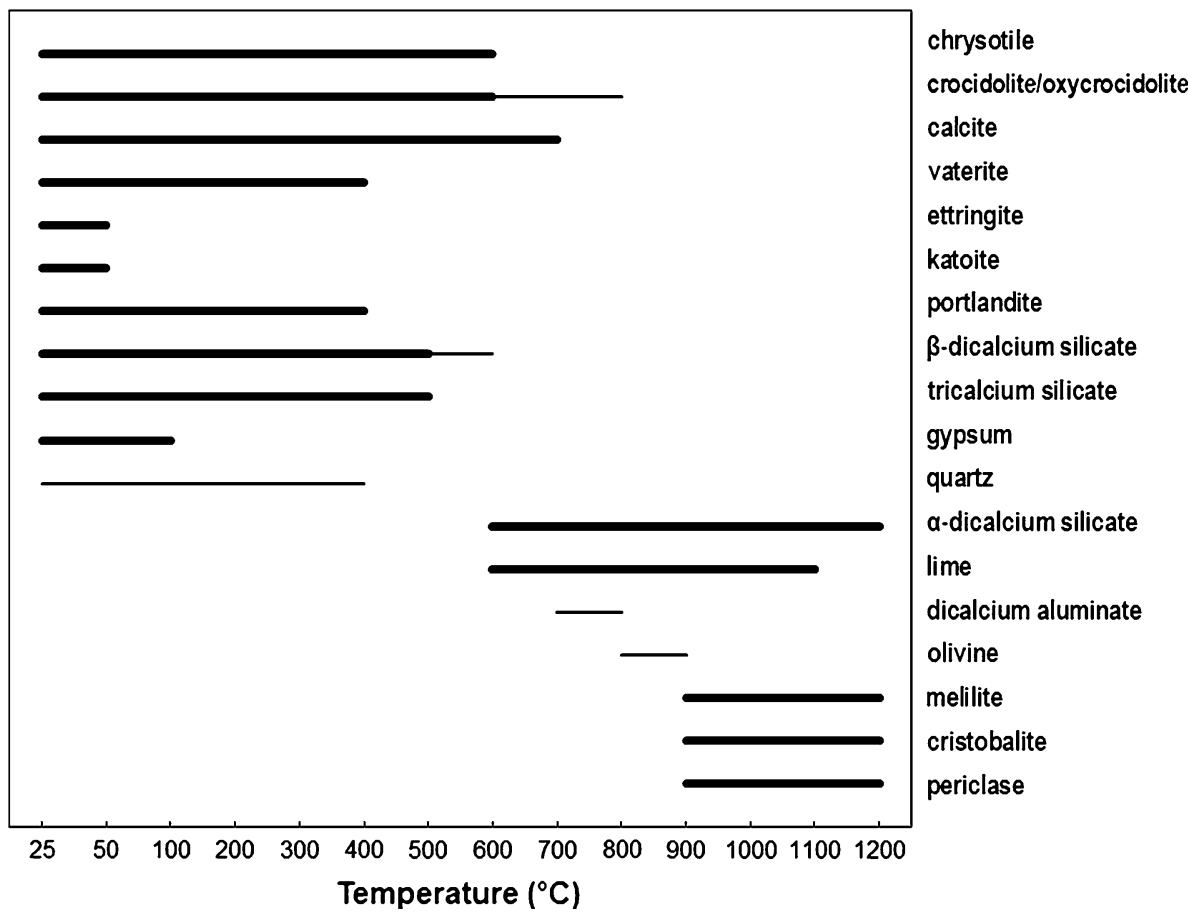

studies [39], where was found that crocidolite asbestos undergoes dehydroxylation process in the temperature range $400-450{ }^{\circ} \mathrm{C}$. Because the in situ diffraction experiment (HT-XRD) was carried out in dynamic conditions, this observation suggests that calcination of cement-asbestos at $700{ }^{\circ} \mathrm{C}$ should already be sufficient for thermal utilisation of asbestos-containing materials. As a result of asbestos minerals thermal decomposition at a higher temperature, traces of olivine $(\mathrm{Mg}, \mathrm{Fe})_{2} \mathrm{SiO}_{4}$ (ICDD-PDF 01-083-0648) were observed. Due to the presence of other phases from the cementitious matrix, products of asbestos thermal decomposition were incorporated into the new phases. Calcite decomposes $\left(\mathrm{CaCO}_{3} \rightarrow \mathrm{CaO}+\mathrm{CO}_{2}\right)$ at about $700-800{ }^{\circ} \mathrm{C}$ and produces large amounts of $\mathrm{CaO}$ (ICDD-PDF 04-006-5940) which is available as a reactant for successive high-temperature reactions. Lime is present up to $1100{ }^{\circ} \mathrm{C}$. The unreacted clinker phases of cement-like $\beta$-dicalcium silicate are stable up to $600{ }^{\circ} \mathrm{C}$ and are then transformed to the high-temperature variety $\left(\alpha-\mathrm{C}_{2} \mathrm{~S}\right.$ in cement notation, $\alpha$-dicalcium silicate) [40]. After thermal treatment at $1200{ }^{\circ} \mathrm{C}$, the periclase (ICDD-PDF 01-0759568), cristobalite (ICDD-PDF 01-075-3164), dicalcium silicate (ICDD-PDF 00-031-0299) and melilite group $\mathrm{Ca}_{2}(\mathrm{Mg}, \mathrm{Fe}, \mathrm{Al}, \mathrm{Si})_{3} \mathrm{O}_{7} \quad$ (ICDD-PDF 04-016-3580) were observed.

Based on these results, a temperature of $700{ }^{\circ} \mathrm{C}$ was selected as a possible minimal value of firing treatment that provides thermal destruction of crocidolite and chrysotile asbestos contained in the cement-asbestos material that we tested. The main mineral components of thermally treated cement-asbestos material (after $2 \mathrm{~h}$ at $700{ }^{\circ} \mathrm{C}$ ) were calcite and dicalcium silicate (Fig. 1). There were also no clearly visible diffraction interferences from the asbestos minerals. The weak interference at $\sim 11^{\circ} 2 \theta$ comes from a relic of crocidolite, so-called oxycrocidolite $\left(\mathrm{Na}_{2} \mathrm{Fe}_{4} \mathrm{FeSi}_{8} \mathrm{O}_{24}\right)$, and is a result of the dehydroxylation process [41]. The external elongate crystal form is probably retained while the internal structure is already changed. This phenomenon is often observed in the case of clay minerals. It should be emphasised that, in accordance with [41], the dehydroxylation process of crocidolite asbestos occurs in a temperature range of $400-500{ }^{\circ} \mathrm{C}$. This was confirmed by an infrared spectroscopy study. After this process, the crocidolite fibres lose their mechanical strength and are easy to crush [41].

The obtained product showed high grinding ability and was easily converted to pulverised shape material without any fibrous structures. This was confirmed by SEM observation (Fig. 4).The SEM micrograph of a cementasbestos sample calcined at $700{ }^{\circ} \mathrm{C}$ and then lightly crushed shows no fibrous asbestos (Fig. 4c). Additional studies were carried out in order to confirm the selected minimal temperature of cement-asbestos calcination.

The results of differential thermal analysis (DTA) combined with thermogravimetric (TG) measurement of both raw and calcined cement-asbestos are reported in Fig. 5. On the DTA curve of raw cement-asbestos waste, four endothermic effects dominated which came from the decomposition of the cementitious matrix. All effects are connected with the mass change. Because of the small 

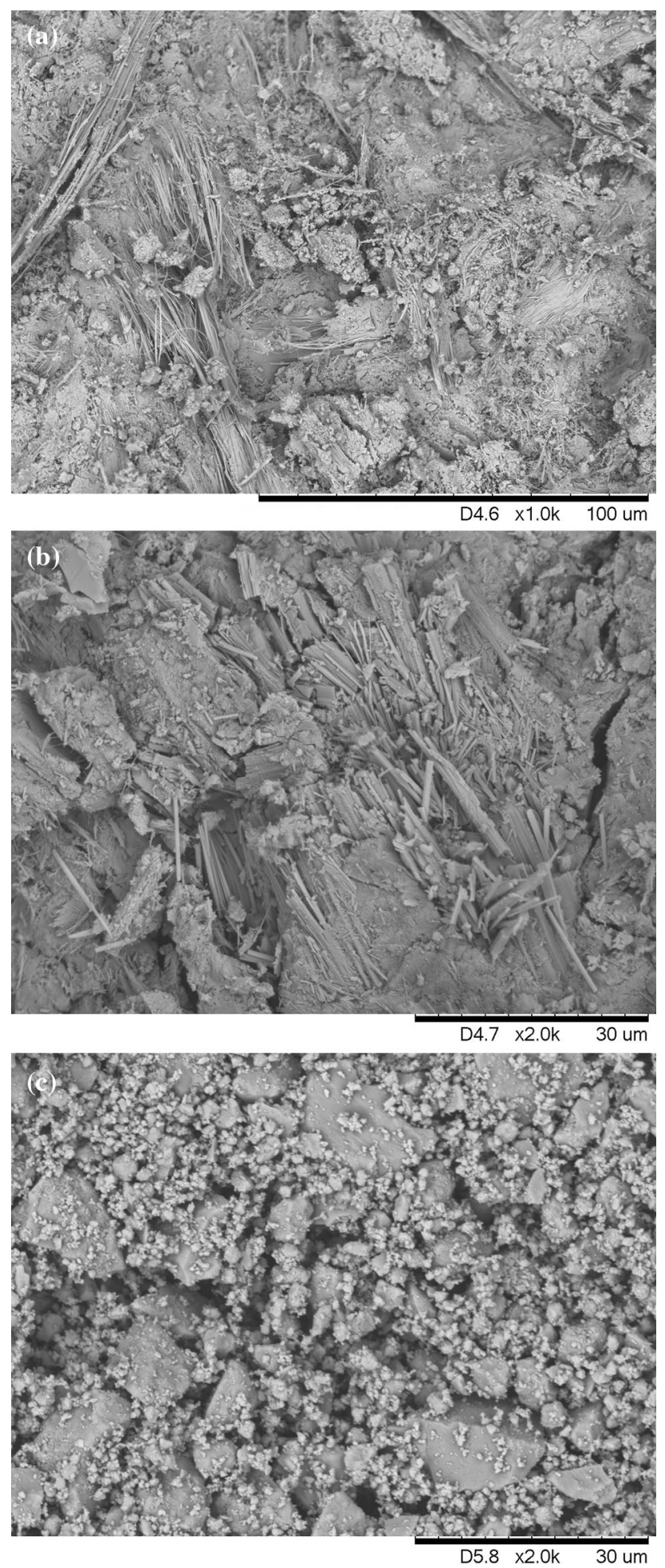

Fig. 4 SEM images of the fracture of raw (a) cement-asbestos sample and after calcination at $700{ }^{\circ} \mathrm{C}$ for $2 \mathrm{~h}$ : unaffected (b) and after soft crush in agate mortar (c)

amount of asbestos minerals in the cement-asbestos material there were no visible characteristic effects from the decomposition of the identified asbestos minerals; these
TG (\%)

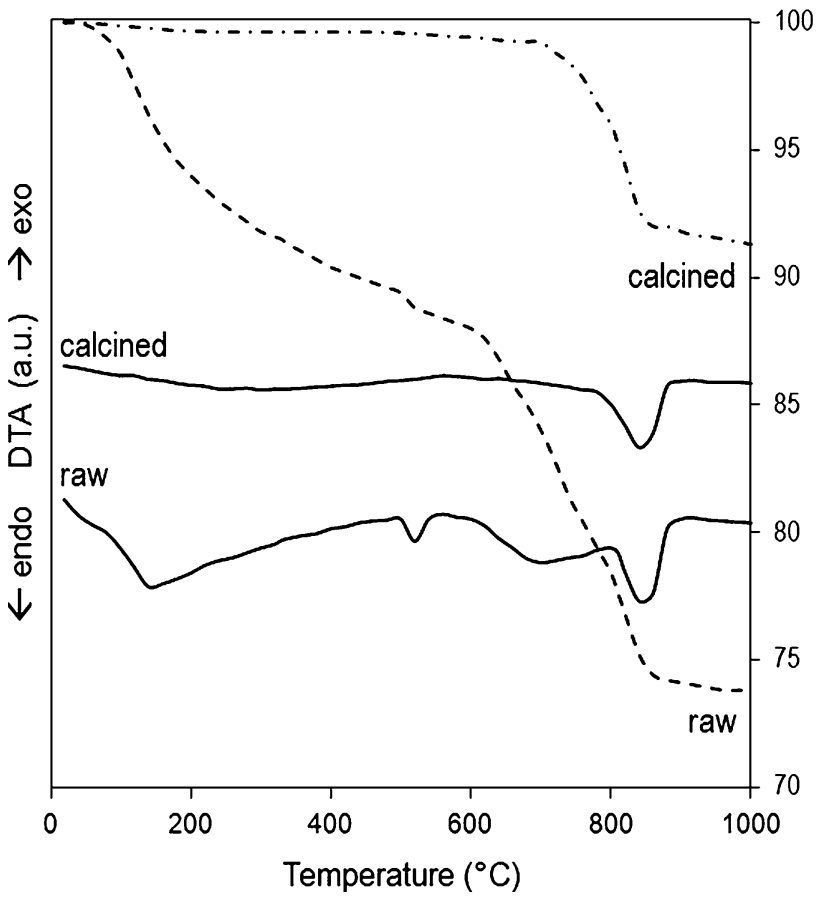

Fig. 5 DTA and TG curves of raw cement-asbestos sample and after thermal treatment at $700{ }^{\circ} \mathrm{C}$ for $2 \mathrm{~h}$

effects were masked by the thermal decomposition of the cementitious matrix components. The first wide endothermic peak is visible in a temperature range of $70-250{ }^{\circ} \mathrm{C}$. This peak is connected mainly with water released from the $\mathrm{CSH}$ phase and AFt/AFm phase (i.e. ettringite and monosulfoaluminate) [42, 43]. The second endothermic peak at $520{ }^{\circ} \mathrm{C}$ indicates the presence of portlandite $\mathrm{Ca}(\mathrm{OH})_{2}$ and its dehydroxylation $\left(\mathrm{Ca}(\mathrm{OH})_{2} \rightarrow \mathrm{CaO}+\mathrm{H}_{2} \mathrm{O}\right)$. In the wide temperature range of $650-800{ }^{\circ} \mathrm{C}$, a third endothermic effect is observed. This wide temperature range of effect may indicate a different degree of crystallinity of the carbonate minerals [31] or the thermal decomposition of cementitious phases, e.g. jennite [44]. The normal singlestep reaction of calcite thermal decomposition is gradually turned into a double-stage reaction by strong weathering conditions, whereas the calcite structure is disintegrated by the weathering process [45]. At a higher temperature (in the range of $800-900{ }^{\circ} \mathrm{C}$ ) the decomposition of wellcrystalline calcite $\left(\mathrm{CaCO}_{3}\right)$ takes place [46]. After isothermal calcination at $700{ }^{\circ} \mathrm{C}$ the most characteristic endothermic effects disappear. Only one effect was observed with a mass change in the range of $800-900{ }^{\circ} \mathrm{C}$ and indicated the presence and thermal decomposition of calcium carbonate $\left(\mathrm{CaCO}_{3} \rightarrow \mathrm{CaO}+\mathrm{CO}_{2}\right)$.

To confirm the thermal decomposition of asbestos minerals included in the cement-asbestos material, sample obtained after calcination was studied by the FT-IR method 


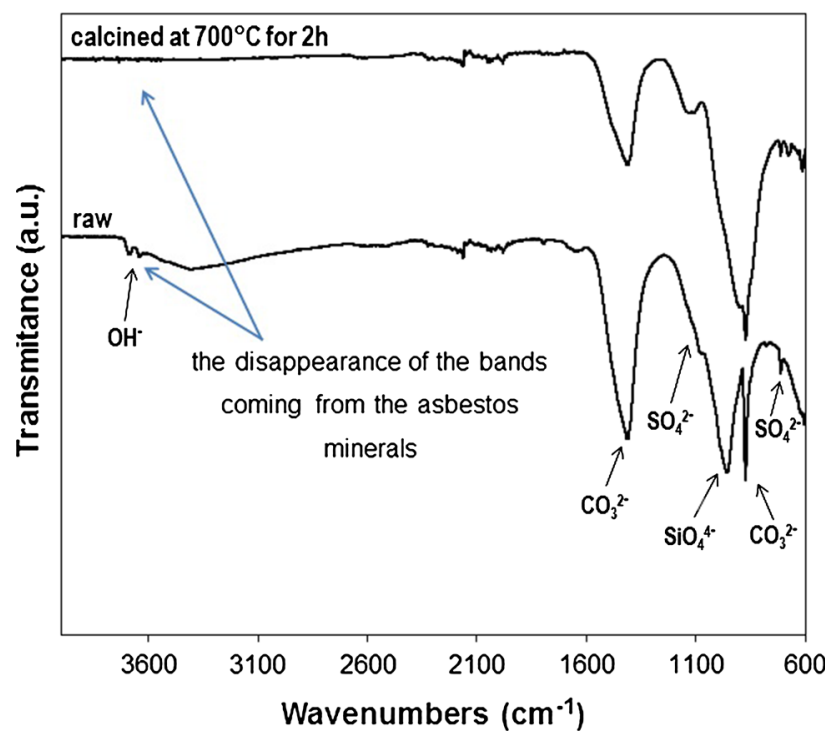

Fig. 6 FT-IR spectra of raw cement-asbestos sample and after thermal treatment at $700{ }^{\circ} \mathrm{C}$ for $2 \mathrm{~h}$

and compared with the IR spectrum of raw cement-asbestos. The results of this study are presented in Fig. 6 . Absorbance bands related to the stretch of $\mathrm{OH}$ groups from asbestos minerals are visible on the FT-IR spectrum of the raw cement-asbestos sample in the high wavenumber region. The IR bands recorded in the region of $1400-1500 \mathrm{~cm}^{-1}$ indicate the presence of carbonates and below $1100 \mathrm{~cm}^{-1}$ are typical of the $\mathrm{Si}-\mathrm{O}-\mathrm{Si}$ stretches in the silica network. Calcination at $700{ }^{\circ} \mathrm{C}$ is sufficient for the asbestos transformation process which causes the disappearance of the characteristic absorption bands of asbestos minerals; the characteristic double band at $3640-3680 \mathrm{~cm}^{-1}$ corresponding to the $\mathrm{OH}$ stretching vibrations of asbestos is lost. A characteristic carbonate band at $\sim 1400 \mathrm{~cm}^{-1}$ remained due to the fact that the thermal treatment temperature was too low. A temperature of thermal treatment equal to $700{ }^{\circ} \mathrm{C}$ is too low for the complete thermal decomposition of calcite. This reaction is only initiated, which is indicated by lower intensity of the IR band.

\section{Recycling of the transformation product in clinker brick mixtures}

In this section of the research previously calcined cementasbestos (at $700{ }^{\circ} \mathrm{C}$ for $2 \mathrm{~h}$ ) was used as a potential secondary raw material for the manufacture of clinker bricks. The results of the physical properties of the obtained clinker ceramic materials (Table 2) show that there is potential for the use of calcined cement-asbestos as a secondary raw material in the production of sintered ceramics.

The values of total linear shrinkage for the masses containing $5 \mathrm{wt} \%$ calcined cement-asbestos waste are at similar level to reference masses (without waste) for all sintering temperatures while those with $10 \mathrm{wt} \%$ shows lower values. The values of total linear shrinkage for these samples are generally decreased by $\sim 1 \%$. Moreover, with increase of the sintering temperature from 1150 to $1200{ }^{\circ} \mathrm{C}$, for all ceramic masses, the inconsiderable decrease of values of this property are observed. It may indicate the initiation of the swelling process and exceeding the optimum firing conditions of ceramics. Confirmation of this fact may be practically no change in the values of apparent density between the samples sintered at 1150 and $1200{ }^{\circ} \mathrm{C}$.

Water absorption as well as open porosity of the ceramic materials obtained on the basis of asbestos materials is generally higher than for comparative samples without any add-on cement-asbestos. The exception is material obtained with $5 \mathrm{wt} \%$ of calcined cement-asbestos and sintered at $1200{ }^{\circ} \mathrm{C}$. In this case lower water absorption was obtained in comparison to the reference material ( 2.7 vs. $3.3 \%$ ). Also, the value of open porosity was the lowest

Table 2 Properties of obtained clinker ceramics based on previously calcined (at $700{ }^{\circ} \mathrm{C}$ for $2 \mathrm{~h}$ ) cement-asbestos

\begin{tabular}{|c|c|c|c|c|c|c|c|c|}
\hline $\begin{array}{l}\text { Cement-asbestos } \\
\text { content }(\%)\end{array}$ & $\begin{array}{l}\text { Mixing } \\
\text { water (\%) }\end{array}$ & $\begin{array}{l}\text { Firing } \\
\text { temperature } \\
\left({ }^{\circ} \mathrm{C}\right)\end{array}$ & $\begin{array}{l}\text { Total linear } \\
\text { shrinkage }(\%)\end{array}$ & $\begin{array}{l}\text { Water } \\
\text { absorption } \\
(\%)\end{array}$ & $\begin{array}{l}\text { Open } \\
\text { porosity } \\
(\%)\end{array}$ & $\begin{array}{l}\text { Apparent } \\
\text { density } \\
\left(\mathrm{g} / \mathrm{cm}^{3}\right)\end{array}$ & $\begin{array}{l}\text { Compressive } \\
\text { strength }(\mathrm{MPa})\end{array}$ & $\begin{array}{l}\text { Freeze } \\
\text { resistance }\end{array}$ \\
\hline \multirow[t]{3}{*}{0} & \multirow[t]{3}{*}{14.5} & 1100 & 7.1 & 5.0 & 11.3 & 2.28 & 35 & Full \\
\hline & & 1150 & 7.8 & 3.8 & 8.6 & 2.30 & 37 & Full \\
\hline & & 1200 & 7.6 & 3.3 & 7.6 & 2.30 & 41 & Full \\
\hline \multirow[t]{3}{*}{5} & \multirow[t]{3}{*}{15.4} & 1100 & 7.1 & 5.9 & 13.8 & 2.19 & 26 & Full \\
\hline & & 1150 & 7.8 & 5.2 & 11.5 & 2.21 & 31 & Full \\
\hline & & 1200 & 7.3 & 2.7 & 6.0 & 2.21 & 35 & Full \\
\hline \multirow[t]{3}{*}{10} & \multirow[t]{3}{*}{15.9} & 1100 & 6.2 & 8.3 & 17.7 & 2.13 & 25 & Full \\
\hline & & 1150 & 6.7 & 7.3 & 15.8 & 2.15 & 31 & Full \\
\hline & & 1200 & 6.1 & 3.9 & 8.4 & 2.16 & 39 & Full \\
\hline
\end{tabular}



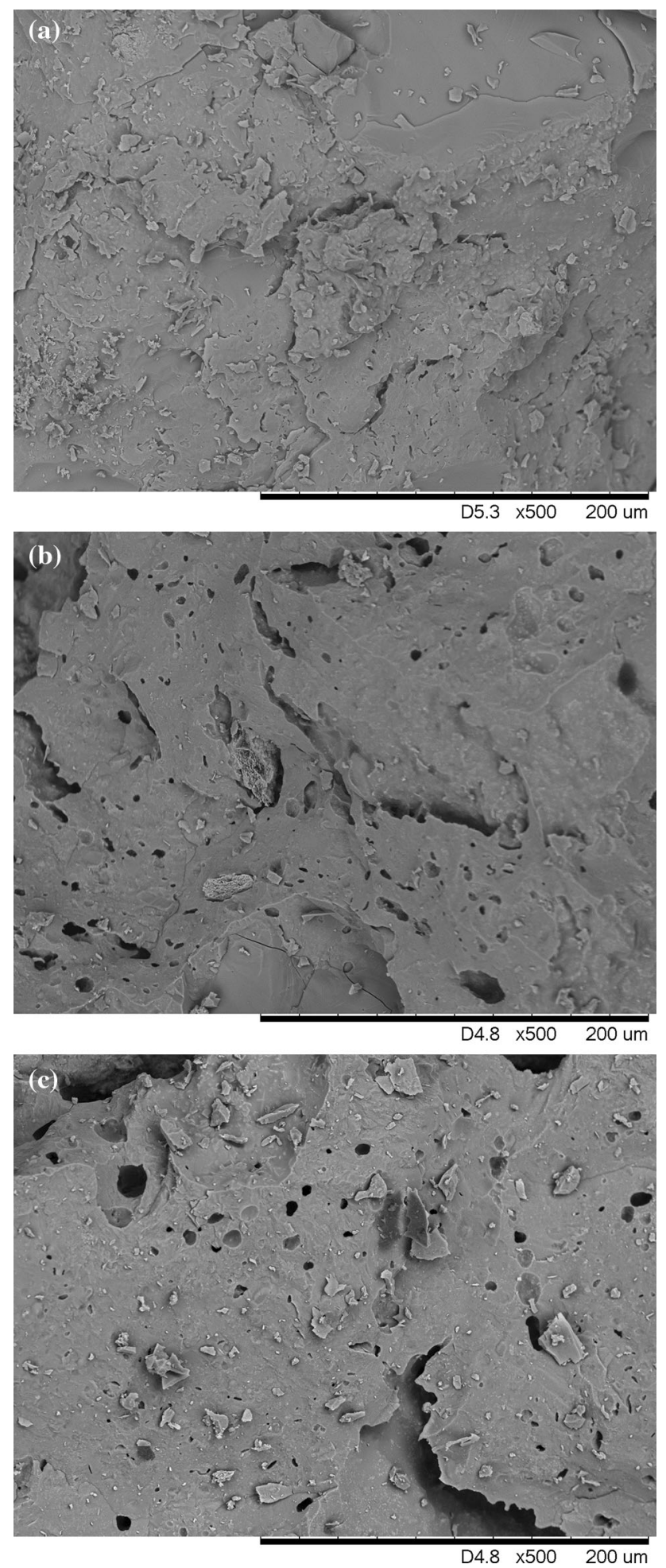

Fig. 7 SEM microphotograph (fracture) of obtained clinker ceramic sintered at $1200{ }^{\circ} \mathrm{C}$ with different amounts of calcined cementasbestos: $0 \mathrm{wt} \%$ (a), $5 \mathrm{wt} \%$ (b) and $10 \mathrm{wt} \%$ (c)

(6\%). Considering the values of water absorption, the most similar results were obtained for materials prepared with the smallest asbestos content, i.e. $5 \mathrm{wt} \%$. The increase of cement-asbestos to $10 \mathrm{wt} \%$ in the ceramic mixtures visibly worsens water absorption. For each sintering temperature, the values of water absorption are higher in comparison to the reference clinker ceramics. However, it should be emphasised that the water absorption of clinker bricks, according to Polish industry standards (PN-B-12008:1996/ Az1:2002), should not exceed $6 \%$ and $10 \%$ for building and road clinker, respectively. In the case of ceramic materials with calcined cement-asbestos addition the requirement for road clinker is fulfilled for each sintering temperature. When the sintering temperature is $1150-1200{ }^{\circ} \mathrm{C}$ for $5 \mathrm{wt} \%$ of cement-asbestos and $1200{ }^{\circ} \mathrm{C}$ for $10 \mathrm{wt} \%$ of calcined asbestos waste, the values of water absorption clearly fall below $6 \%$ and the obtained ceramic material can be classified as building clinker ceramics.

The obtained results of compressive strength are also satisfactory. Compressive strength for clinker should be in the range of 22-75 MPa. The values of compressive strength for the obtained clinker ceramics with cementasbestos were in the range of $25-40 \mathrm{MPa}$, thus the standard requirements are fulfilled. It should be noted that the addition of $10 \mathrm{wt} \%$ of cement-asbestos did not reduce the compressive strength of ceramic material as compared to the sample with $5 \mathrm{wt} \%$ of this waste. Moreover, for a sintering temperature of 1100 and $1150{ }^{\circ} \mathrm{C}$ the values are almost identical. The obtained ceramic materials have full freeze resistance, i.e. they can withstand 25 cycles of freezing and thawing in a temperature range from $-25{ }^{\circ} \mathrm{C}$ to room temperature.

Characteristic microstructure images of the fracture of the obtained ceramic materials are shown in Fig. 7. A small amount of cement-asbestos (5 wt $\%$ ) in the ceramic mixtures does not significantly influence the resulting ceramic materials as compared to materials without asbestos wastes. The SEM images are very similar. Increasing the cement-asbestos content to $10 \mathrm{wt} \%$ caused clear and visible differences in the microstructure of the resulting clinker brick material, which became more porous.

\section{Conclusions}

Thermal treatment is one of the possible and useful methods of cement-asbestos detoxification. This study describes the reaction path and phase composition change that take place during the calcination of cement-asbestos slate containing chrysotile and crocidolite asbestos up to the thermal treatment temperature of $1200{ }^{\circ} \mathrm{C}$. As a result of this process the dangerous structure of asbestos minerals is destroyed. The study showed that calcination of cementasbestos (based on chrysotile and crocidolite variety of asbestos) at $700{ }^{\circ} \mathrm{C}$ is sufficient for thermal utilisation and that it contained absolutely no residual asbestos. The 
obtained product has high grinding ability and is easily milled to pulverent material. In the second part of the research it was proved that thermally treated cement-asbestos at a temperature of $700{ }^{\circ} \mathrm{C}$ can be safely recycled as a secondary raw material in the manufacture of clinker ceramics. The addition of $5 \mathrm{wt} \%$ of calcined cement-asbestos material does not yield significant variations to the reference material and to the standard production parameters, e.g. water absorption, compressive strength or freeze resistance, of clinker bricks.

Open Access This article is distributed under the terms of the Creative Commons Attribution 4.0 International License (http://crea tivecommons.org/licenses/by/4.0/), which permits unrestricted use, distribution, and reproduction in any medium, provided you give appropriate credit to the original author(s) and the source, provide a link to the Creative Commons license, and indicate if changes were made.

\section{References}

1. Sporn TA (2011) Mineralogy of asbestos. In: Tannapfel A (ed) Malignant mesothelioma. Springer, Berlin, pp 1-11

2. Virta RL (2005) Mineral commodity profiles-Asbestos. U.S. Geological Survey Circular 1255-KK, Reston

3. Czekaj A, Dyczek J (2002) Korozja wyrobów azbestowo-cementowych i wynikające z niej ryzyko emisji azbestu (in Polish). Cement Wapno Beton 6:270-275

4. Bensted J, Smith JR (2011) Asbestos legacy impacts on future prospects. Cement Wapno Beton 3:161-166

5. LaDou J, Castleman B, Frank A, Gochfeld M, Greenberg M, Huff J, Joshi TK, Landrigan PJ, Lemen R, Myers J, Soffritti M, Soskolne CL, Takahashi K, Teitelbaum D, Terracini B, Watterson A (2010) The case for global ban on asbestos. Environ Health Perspect 118:897-901. doi:10.1289/ehp.1002285

6. Demirogiu H (1998) Hazard of white asbestos. Lancet 352:322-323. doi:10.1016/S0140-6736(05)60298-X

7. Langer AM (2003) Reduction of the biological potential of chrysotile asbestos arising from conditions of service on brake pads. Regul Toxicol Pharm 38:71-77. doi:10.1016/S02732300(03)00070-9

8. Dyczek J (2006) Eksploatacja i usuwanie wyrobów zawierających azbest (in Polish). Mater Bud 11:46-48

9. Sugama T, Sabatini R, Petrakis L (1998) Decomposition of chrysotile asbestos by fluorosulfonic acid. Ind Eng Chem Res 37:79-88. doi:10.1021/ie9702744

10. Turci S, Tomatis M, Mantegma S, Cravotto G, Fubini B (2007) The combination of oxalic acid with power ultrasound fully degrades chrysotile asbestos fibres. J Environ Monit 9:1064-1066. doi:10.1039/b709571f

11. Yanagisawa K, Kozawa T, Onda A, Kanazawa M, Shinohara J, Takanami T, Shiraishi M (2009) A novel decomposition technique of friable asbestos by $\mathrm{CHClF}_{2}$-decomposed acidic gas. J Hazard Mater 163:593-599. doi:10.1016/j.jhazmat.2008.07.017

12. Rozalen M, Javier Huertas F (2013) Comparative effect of chrysotile leaching in nitric, sulfuric and oxalic acids at room temperature. Chem Geol 352:134-142. doi:10.1016/j.chemgeo. 2013.06.004

13. Dellisanti F, Rossi PL, Valdre G (2009) Remediation of asbestos containing materials by Joule heating vitrification performed in a pre-pilot apparatus. Int J Miner Process 91:61-67. doi:10.1016/j. minpro.2008.12.001
14. Leonelli C, Veronesi P, Boccaccini DN, Rivasi MR, Barbieri L, Andreola F, Lancellotti I, Rabitti D, Pellacani GC (2006) Microwave thermal inertisation of asbestos containing waste and its recycling in traditional ceramics. $\mathrm{J}$ Hazard Mater B135:149-155. doi:10.1016/j.jhazmat.2005.11.035

15. Osada M, Takamiya K, Manako K, Noguchi M, Sakai S (2013) Demonstration study of high temperature melting for asbestoscontaining waste $(\mathrm{ACW})$. J Mater Cycles Waste Manag 15:25-36. doi:10.1007/s10163-012-0088-3

16. Plescia P, Gizzi D, Benedetti S, Camilucci L, Fanizza C, Simone De, Paglietti F (2003) Mechanochemical treatment to recycling asbestos-containing waste. Waste Manag 23:209-218. doi:10. 1016/S0956-053X(02)00156-3

17. Colangelo F, Cioffi R, Lavorgna M, Verdolotti L, De Stefano L (2011) Treatment and recycling of asbestos-cement containing waste. J Hazard Mater 195:391-397. doi:10.1016/j.jhazmat.2011. 08.057

18. Favero-Longo SE, Turci F, Tomatis M, Castelli D, Bonfante P, Hochella M, Piervittori R, Fubini B (2005) Chrysotile asbestos is progressively converted into a non-fibrous amorphous material by the chelating action of lichen metabolites. J Environ Monit 7:764-766. doi:10.1039/B507569F

19. Dellisanti F, Minguzzi V, Morandi N (2001-2002) Experimental results from thermal treatment of asbestos containing materials. GeoActa 1:61-70

20. Hashimoto S, Takeda H, Okuda A, Kamayashi A, Honda S, Iwamoto Fukuda K (2008) Detoxification of industrial asbestos waste by low-temperature heating in a vacuum. J Ceram Soc Jpn 116:242-246

21. Gualtieri AF, Lassinantti Gualtieri M, Tonelli M (2008) In situ ESEM study of the thermal decomposition of chrysotile asbestos in view of safe recycling of the transformation product. J Hazard Mater 156:260-266. doi:10.1016/j.jhazmat.2007.12.016

22. Kusiorowski R, Zaremba T, Piotrowski J, Gerle A (2013) Thermal decomposition of asbestos-containing materials. J Therm Anal Calorim 113:179-188. doi:10.1007/s10973-013-3038-y

23. Zaremba T, Peszko M (2008) Investigation of the thermal modification of asbestos wastes for potential use in ceramic formulation. J Therm Anal Calorim 92:873-877. doi:10.1007/s10973007-8111-y

24. Gualtieri AF, Giacobbe C, Sardisco L, Saraceno M, Lassinantti Gualtieri M, Lusvardi G, Cavenati C, Zanatto I (2011) Recycling of the product of thermal inertization of cement-asbestos for various industrial applications. Waste Manag 31:91-100. doi:10. 1016/j.wasman.2010.07.006

25. Zaremba T, Krząkała A, Piotrowski J, Garczorz D (2011) Investigations of chrysotile asbestos application for sintered ceramic obtaining. Mater Ceram 63:80-84

26. Zhu P, Wang LY, Hong D, Zhou M, Zhou J (2013) Investigative studies for inert transformation of toxic chrysotile tailing. J Mater Cycles Waste Manag 15:90-97. doi:10.1007/s10163-012-0093-6

27. Gualtieri AF, Tartaglia A (2000) Thermal decomposition of asbestos and recycling in traditional ceramics. J Eur Ceram Soc 20:1409-1418. doi:10.1016/S0955-2219(99)00290-3

28. Zaremba T, Krząkała A, Piotrowski J, Garczorz D (2010) Study on the thermal decomposition of chrysotile asbestos. J Therm Anal Calorim 101:479-485. doi:10.1007/s10973-010-0819-4

29. Kusiorowski R, Zaremba T, Piotrowski J, Adamek J (2012) Thermal decomposition of different types of asbestos. J Therm Anal Calorim 109:693-704. doi:10.1007/s10973-012-2222-9

30. Teixeira APC, Santos EM, Vieira AFP, Lago RM (2013) Use of chrysotile to produce highly dispersed $\mathrm{K}$-doped $\mathrm{MgO}$ catalyst for biodiesel synthesis. Chem Eng J 232:104-110. doi:10.1016/j.cej. 2013.07.065

31. Dias CMR, Cincotto MA, Savastano H, John VM (2008) Longterm aging of fiber-cement corrugated sheets-the effect of 
carbonation, leaching and acid rain. Cem Concr Compos 30:255-265. doi:10.1016/j.cemconcomp.2007.11.001

32. Gualtieri AF, Cavenati C, Zanatto I, Meloni M, Elmi G, Lassinantti Gualtieri M (2008) The transformation sequence of cement-asbestos slates up to $1200{ }^{\circ} \mathrm{C}$ and safe recycling of the reaction product in stoneware tile mixtures. J Hazard Mater 152:563-570. doi:10.1016/j.jhazmat.2007.07.037

33. Belardi G, Piga L (2013) Influence of calcium carbonate on the decomposition of asbestos contained in end-of-life products. Thermochim Acta 573:220-228. doi:10.1016/j.tca.2013.08.019

34. Viani A, Gualtieri AF, Secco M, Peruzzo L, Artioli G, Cruciani G (2013) Crystal chemistry of cement-asbestos. Am Miner 98:1095-1105. doi:10.2138/am.2013.4347

35. Viani A, Gualtieri AF, Pollastri S, Rinaudo C, Croce A, Urso G (2013) Crystal chemistry of the high temperature product of transformation of cement-asbestos. J Hazard Mater 248-249:69-80. doi:10.1016/j.jhazmat.2012.12.030

36. Witek J, Mróz H, Barański J, Brach J (2012) Neutralisation of asbestos-containing waste using the method of melting in an arcresistance furnace (in Polish). Sci Works Inst Ceram Build Mater 11:146-158

37. Antao SM, Duane MJ, Hassan I (2002) DTA, TG and XRD studies of sturmanite and ettringite. Can Miner 40:1403-1409. doi:10.2113/gscanmin.40.5.1403

38. Popescu MA, Isopescu R, Matei C, Fagarasan G, Plesu V (2014) Thermal decomposition of calcium carbonate polymorphs precipitated in the presence of ammonia and alkylamines. Adv Powder Technol 25:500-507. doi:10.1016/j.apt.2013.08.003

39. Kusiorowski R, Zaremba T, Gerle A, Piotrowski J, Simka W, Adamek J (2015) Study on the thermal decomposition of crocidolite asbestos. J Therm Anal Calorim 120:1585-1595. doi:10.1007/s10973-015-4421-7

40. Yamnova NA, Zubkova NV, Eremin NN, Zadov AE, Gazeev VM (2011) Crystal structure of larnite $\beta-\mathrm{Ca}_{2} \mathrm{SiO}_{4}$ and specific features of polymorphic transitions in dicalcium orthosilicate. Crystallogr Rep 56:210-220. doi:10.1134/S1063774511020209

41. Hodgson AA, Freeman AG, Taylor HFW (1965) The thermal decomposition of crocidolite from Koegas, South Africa. Miner Mag 35(269):5-30

42. Bădănoiu A, Paceagiu J, Voicu G (2011) Hydration and hardening processes of Portland cements obtained from clinkers mineralized with fluoride and oxides. J Therm Anal Calorim 103:879-888. doi:10.1007/s10973-010-1125-x

43. Perez-Rodriguez JL, Duran A, Perez-Marqueda LA (2011) Thermal study of unaltered and altered dolomitic rock samples from ancient monuments. J Therm Anal Calorim 104:467-474. doi:10.1007/s10973-011-1348-5

44. Stepkowska ET, Blanes JM, Real C, Perez-Rodriguez JL (2004) Phase transformation on heating of an aged cement paste. Thermochim Acta 420:79-87. doi:10.1016/j.tca.2003.11.05

45. Földvári M (2011) Handbook of thermogravimetric system of minerals and its use in geological practice. Geological Institute of Hungary, Budapest

46. Pacewska B, Wilińska I, Nowacka M (2011) Studies on the influence of different fly ashes and Portland cement on early hydration of calcium aluminate cement. J Therm Anal Calorim 106:859-868. doi:10.1007/s10973-011-1570-1 